\title{
The Determinants of U.S. Labor Disputes
}

\author{
Peter C. Cramton, University of Maryland \\ Joseph S. Tracy, Columbia University \\ Journal of Labor Economics, 12, 180-209, 1994
}

\begin{abstract}
We present a bargaining model of union contract negotiations, in which the union decides between two threats: the union can strike or continue to work under the expired contract. The model makes predictions about the level of dispute activity and the form the disputes take. Strike incidence increases as the strike threat becomes more attractive, because of low unemployment or a real wage drop during the prior contract. We test these predictions by estimating logistic models of dispute incidence and dispute composition for U.S. labor contract negotiations from 1970 to 1989. We find empirical support for the model's key predictions, but these associations are weaker after 1981.
\end{abstract}

\section{Introduction}

In union contract negotiations in the U.S. and other countries, the union has two options if an agreement has not been reached by the contract expiration date. The union can strike or it can continue to work under the terms of the expired contract, which we call holdout. We present a strategic model of wage bargaining based on Cramton and Tracy (1992) that includes this threat decision.

A main purpose of this and other bargaining models with private information is to understand why we frequently observe costly disputes. ${ }^{1}$ Rational and fully informed bargainers should be able to identify an efficient agreement that reflects their strategic positions. If they can predict where they will settle after a costly dispute, then what prevents them from settling at those terms today? Introducing private information is a simple way of explaining costly disputes. If one or both of the parties has private information about some aspect critical to the negotiations, then the incentive to misrepresent this information leads to bargaining inefficiencies. For example, if the union is unsure about the firm's willingness to pay, the firm has an incentive to understate this value. The firm can claim that times are tough and that it cannot pay much, but the union will distrust the firm unless its claims can be made credible. ${ }^{2}$ One means of convincing the union that times are tough is for the firm to withstand a long strike. If the firm is highly profitable, it prefers to avert a strike by accepting a higher wage settlement; if the firm is less profitable, it prefers to endure a strike in order to settle at a lower wage. ${ }^{3}$

Thus far, the economic literature has focused mostly on strikes, ignoring that the union actually decides between two threats, strike or holdout (continuing to work under the terms of the expired contract). In this paper, we highlight the important implications of the union's threat decision. Our main result is that the union's threat decision is sensitive to economic and policy changes. These changes alter the relative attractiveness of the threats, leading to shifts in the composition of disputes. The attractiveness of the holdout threat is determined from what the workers get paid during a holdout,

We have benefited from comments by seminar participants at Cal Tech, Chicago, Colorado, Columbia, Harvard, Iowa, Maryland, Stanford, Stony Brook, Washington, and Wisconsin. Funding has been provided by National Science Foundation grant SES-9122707.

\footnotetext{
${ }^{1}$ See Kennan and Wilson $(1989 ; 1990 ; 1993)$ for surveys of bargaining models with private information and their relation to strike data. See Card (1990a) and Kennan (1986) for surveys of the empirical results on strike activity.

${ }^{2}$ A recent example appeared on the front page of the New York Times (28 October 1990), describing the negotiations between New York City and its municipal workers. "At the core of the stalled New York City municipal labor talks is the union leaders' growing distrust of the claims being made about the city's financial plight." One union leader said, "Every year under Mayor Koch they forecast a deficit, yet every year we had a surplus." Another called the city budget director, "more full of it than a Christmas turkey."

${ }^{3}$ Anecdotal evidence for this story is found in the documentary, Final Offer, of the 1984 negotiations between General Motors Canada and the United Auto Workers. During the fifth day of the strike, the union leaders are discussing whether they should accept GM's most recent offer. One leader said, "You might convince me that that's all there is after a month, but not after five days." Another representative said, "If they think it will take a short strike to convince workers to accept, they're wrong."
} 
namely the current wage under the expired contract. Similarly, the attractiveness of the strike threat is largely determined by the workers' outside employment options. This leads to two predictions of the model. First, if the real wage falls during the prior contract because of uncompensated inflation, then the holdout threat becomes less attractive and we should observe a shift in the composition of disputes from holdout to strike. Second, if the workers' outside employment opportunities improve because of a decline in local unemployment, we should observe a similar shift in the composition of disputes: the strike threat becomes more attractive, making strikes more likely to occur. These predictions are driven by shifts in the composition of disputes resulting from the union's threat decision. They do not arise in a model in which the strike threat is the union's only option. In a strike-only model, strike incidence is unaffected by a drop in the real wage, and is only slightly affected by a decrease in local unemployment.

In theory, a holdout is a productive inefficiency without a strike caused by a breakdown of cooperation. This breakdown can occur either before or after the contract expiration date, but since we do not observe the actual date of breakdown, we define holdouts in terms of what we do observe the contract expiration date. We assume that holdouts begin one day after contract expiration. This is motivated from a fact and a story. The fact is a strong deadline effect at the contract expiration date (Cramton and Tracy 1992). The story is an implicit understanding that the parties maintain through reputations. During a contract, both sides implicitly agree to cooperate with one another so long as the contract is not broken. Once the contract has expired, the union is free to use its most effective bargaining weapon to secure a favorable contract. The union can wait to apply the threat, but it is better off employing the threat as soon as possible. Waiting simply postpones the bargaining gains.

To evaluate the implications of economic and policy changes on dispute activity, we fit the parameters of our model to the descriptive statistics from a large sample of contract negotiations. Creating this benchmark model permits us to make detailed predictions on how economic changes influence dispute activity. Strike incidence is shown to be highly elastic to changes in the real wage and in the workers' outside employment options. We test these predictions by estimating logistic models of dispute incidence and dispute composition using data on major U.S. contract negotiations from 1970 to 1989. We find empirical support for the model's key predictions, but that these associations are much weaker in the post 1981 period. An interpretation of these findings is that the threat of permanent replacement in the post 1981 period may have diminished the attractiveness of the strike threat.

Section II reviews the model of wage bargaining from Cramton and Tracy (1992). Then in Section III, we establish a benchmark case by fitting the parameters of the model to the descriptive statistics in our sample. Section IV determines how sensitive the equilibrium outcome is to changes in the model parameters. In Sections V and VI, we describe an empirical specification of our model and present estimates of the determinants of dispute incidence and dispute composition. Section VII examines the issue of whether a structural change in the empirical model occurred in the post 1981 period.

\section{A Model of Wage Bargaining}

Our model of wage bargaining is based on Cramton and Tracy (1992). A union and a firm are bargaining over the wage to be paid during a contract of duration $T{ }^{4}$ The union's reservation wage is common knowledge. Let $v$ be the firm's value of the current labor force working under a contract of duration $T$. The value $v$ is known only to the firm, but it is common knowledge that $v$ is drawn from the distribution $F$ with positive density on the interval $[\ell, h]$.

Bargaining begins with the union selecting a threat $\theta \in\{H, S\}$, either holdout or strike, which applies until a settlement is reached. ${ }^{5}$ In the threat $\theta$, the payoff to the union is $x_{\theta}$ and the payoff to the

\footnotetext{
${ }^{4}$ For simplicity, we analyze a single contract negotiation. Thus we ignore any linkages with other negotiations, either over time or within the industry. Also, the contract length $T$ is assumed fixed. A more realistic model would relax these strong assumptions, but such an analysis is beyond the scope of this paper.

${ }^{5}$ We are assuming that the threat decision is made on the day the contract expires and remains in place until an agreement is reached. Cramton and Tracy (1993) allows for the possibility of switching threats during a dispute. For example, the union may adopt a strike deadline in which it initiates a strike after a period of holdout. Although a majority of strikes in our data begin within two days of the contract expiration, transitions from holdout to strike are common as well. We ignore lockouts because they are rarely observed in our data. Only $3 \%$ of work stoppages are lockouts.
} 
firm is $y_{\theta}(v)=a_{\theta} v-b_{\theta}$, where $a_{\theta} \in[0,1)$ and $b_{\theta} \geq 0$. The term $1-a_{\theta}$, which we call the dispute cost, measures how far the parties are from the Pareto frontier during the threat $\theta$. We define $c_{\theta}=\left(b_{\theta}-x_{\theta}\right) /(1-$ $\left.a_{\theta}\right)$ to be the relative payment difference during the threat $\theta$ : what the firm pays less what the union gets divided by the dispute cost. Since the total payoff in agreement is $v$ and the total payoff in the threat is $a_{\theta} v-b_{\theta}+x_{\theta}$, the pie that the parties are bargaining over is $\left(1-a_{\theta}\right) v+b_{\theta}-x_{\theta}=\left(1-a_{\theta}\right)\left(v+c_{\theta}\right)$. We assume that this pie is positive for all $v \in[\ell, h]$, which implies $c_{\theta}>-\ell$.

Let $w_{0}$ be the current wage under the expired contract. Under U.S. labor law, the workers are paid the current wage $w_{0}$ during a holdout, so $b_{H}=x_{H}=w_{0}$ and $c_{H}=0$. We assume there is some inefficiency associated with a holdout: $a_{H}<1$. This inefficiency can come from several sources. (1) During a holdout the workers have an incentive to slow down or "work to rule" work exactly according to the rules of the expired contract and no more. There are frequent discussions of this in the press. ${ }^{6}(2)$ The work rules of the expired contract may be inefficient due to technology changes during the prior contract. ${ }^{7}$ (3) Customers and suppliers may be reluctant to deal with the firm after contract expiration, because of the disruption that a potential strike might cause. ${ }^{8}$ It would be difficult to measure the holdout inefficiency precisely (or the strike inefficiency for that matter). Our main result, however, that strike and holdout incidences are sensitive to economic and policy changes, holds regardless of the size of the holdout inefficiency. For all values of $a_{H}$, the union is faced with a choice between the strike or holdout threats. The tradeoffs involved in that choice critically depend on economic and policy variables.

An outcome of the bargaining, denoted $\langle t, w, \theta\rangle$, specifies the time of agreement $t \in[0, T]$, the contract wage $w$ at the time of agreement, and the threat $\theta \in\{H, S\}$ before agreement. We assume that the union and firm are risk neutral and that the payoff flows, both during the threat and after agreement, are constant over time. ${ }^{9}$ The overall payoffs, then, are calculated as a combination of the threat payoff and the agreement payoff, weighted by the fraction of time spent in each outcome, as shown in Figure 1.

Define

$$
D(t)=\frac{1-e^{-r t}}{1-e^{-r T}}
$$

\footnotetext{
${ }^{6}$ One recent example is the contract negotiations between American Airlines and its pilots, who used a number of tactics to reduce productivity during negotiations. These tactics included: (1) sickouts during busy periods, resulting in canceled flights, (2) last minute arrival, resulting in delayed flights, (3) lowering landing gear early and flying at lower altitudes to waste fuel, and (4) refusing to do visual landings, thereby requiring a longer approach, which wastes fuel and time. American Airlines placed a fullpage add in the New York Times on 7 January 1991 to apologize to its passengers inconvenienced by these job actions.

${ }^{7}$ A production inefficiency at the Daily News is a good example. New presses needed only eight operators. The work rules, however, required that there be thirteen operators at each press (New York Times, 28 October 1990).

${ }^{8}$ In the week prior to the 30 June 1990 contract expiration at U.P.S., customers were warned by union employees that packages might not be delivered, because of the possibility of a strike after the contract expiration. As a result, some customers switched to other carriers until a contract was signed.

${ }^{9}$ Time-varying threats are considered in Cramton and Tracy (1993). Such threats are important to study, since threat payoffs often do change during a dispute. For example, during a strike, production might be low initially, but then increase as the firm hires and trains replacement workers. Time-varying threats can significantly affect the bargaining outcome. However, the basic qualitative features of the two models are the same.
} 


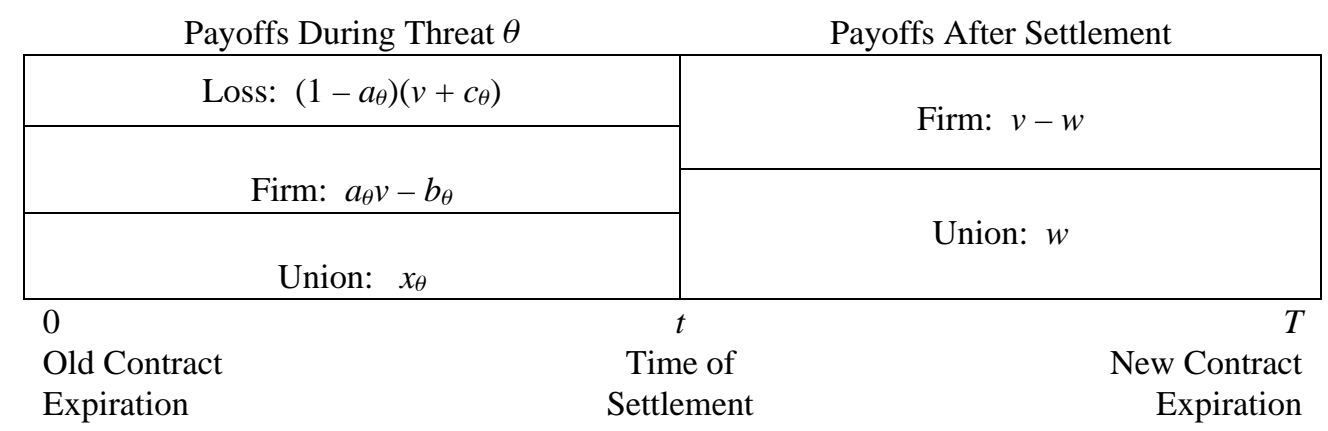

FIG. 1.- Payoffs from bargaining outcome $\langle t, w, \theta\rangle$

to be the discounted fraction of time spent in dispute if agreement occurs at time $t$, where $r$ is the discount rate. Then given the outcome $\langle t, w, \theta\rangle$, the union's payoff is

$$
U(t, w, \theta)=x_{\theta} D(t)+w(1-D(t))
$$

and the firm's payoff is

$$
V(t, w, \theta)=y_{\theta}(v) D(t)+(v-w)(1-D(t)) .
$$

After the union's threat choice, the union and firm alternate wage offers, with the union making the initial offer. After an offer is made, the other side has two possible responses: (1) a counteroffer, in which case the bargaining continues, or (2) acceptance, in which case the bargaining ends with labor supplied at the offered wage for the remainder of the contracting period T. As in Admati and Perry (1987), a bargainer can delay responding to an offer. This assumption leads to the signaling equilibrium in which the firm signals its value through its willingness to delay agreement. ${ }^{10}$ For simplicity, we assume that the minimum time between offers is arbitrarily small. This is the interesting case, since in practice one observes a minimum time between offers that is small relative to plausible discount rates. Moreover, in the signaling equilibrium we derive, the outcome is insensitive to the assumed time between offers.

The equilibrium takes a simple form. If $w_{0}$ is sufficiently low (below an indifference level) the union decides to strike; otherwise $\left(w_{0} \geq \widetilde{w}\right)$ the union decides to hold out. The indifference level depends on $r$, $T, F$, and the threat payoffs $\left(x_{\theta}, y_{\theta}\right)$ for $\theta=\{H, S\}$. A second indifference level $m \in(\ell, h)$ is determined by the union's initial offer. The firm accepts the union's initial offer if its valuation is above $m$ and otherwise rejects the offer.

The signaling equilibrium is characterized in the following three propositions from Cramton and Tracy (1992). First we look at the subgame after a threat $\theta \in\{H, S\}$ is chosen.

PROPOSITION 1. Let $\theta=\left(x_{\theta}, y_{\theta}\right)$ be the threat chosen by the union. In the limit as the time between offers goes to zero, there is a perfect Bayesian equilibrium with the following form:

1. The union makes an immediate offer of $w_{\theta}(m)=x_{\theta}+1 / 2\left(1-a_{\theta}\right)\left(m+c_{\theta}\right)$, where $m\left(c_{\theta}\right) \in(\ell, h)$ maximizes

$$
\left(m+c_{\theta}\right)(1-F(m))+\int_{\ell}^{m} \frac{\left(v+c_{\theta}\right)^{2}}{m+c_{\theta}} d F(v) .
$$

\footnotetext{
${ }^{10}$ The same equilibrium can be derived from the more standard Rubinstein (1982) extensive form with a fixed time between offers (Ausubel and Deneckere 1991). We focus on the signaling equilibrium because it is simple and has desirable qualitative properties.
} 
2. The firm accepts the offer if $v \geq m$. Otherwise, if $v<m$, the firm waits until $(m-v) /\left(m+c_{\theta}\right)$ of the contract period has passed before offering $w_{\theta}(v)=x_{\theta}+1 / 2\left(1-a_{\theta}\right)\left(v+c_{\theta}\right)$, which is accepted immediately by the union.

3. The union's expected payoff from the threat $\theta$ is $U_{\theta}$, the firm's expected payoff is $V_{\theta}$, and the expected loss is $L_{\theta}$, where

$$
\begin{gathered}
U_{\theta}=x_{\theta}+\left(1-a_{\theta}\right)\left(m+c_{\theta}\right)(1-F(m)) \\
V_{\theta}=a_{\theta} E(v)-b_{\theta}+\left(1-a_{\theta}\right) \int_{m}^{h}\left(v+c_{\theta}\right) d F(v)
\end{gathered}
$$

and

$$
L_{\theta}=\left(1-a_{\theta}\right)\left[c_{\theta}-\left(m+2 c_{\theta}\right)(1-F(m))+\int_{\ell}^{m} v d F(v)\right] .
$$

For a given threat $\theta$, we can determine how dispute incidence and duration respond to changes in the threat $\theta$ or to changes in the distribution of $v$. The following proposition says that dispute activity increases with uncertainty. Dispute activity also increases when the threat $\theta$ becomes more attractive to the union $\left(c_{\theta}\right.$ falls $)$.

PROPOSITION 2. Suppose that $m\left(c_{\theta}\right)$ uniquely maximizes (1). Dispute incidence $F\left(m\left(c_{\theta}\right)\right)$ and dispute duration $D\left(v, c_{\theta}\right)=\left(m\left(c_{\theta}\right)-v\right) /\left(m\left(c_{\theta}\right)+c_{\theta}\right)$ increase as $c_{\theta}$ decreases. Likewise, dispute incidence and dispute duration increase with a linear, mean-preserving spread of the distribution $F$.

Dispute activity in this model depends on the amount of uncertainty about private information. Interestingly, there is no necessary relationship between dispute activity and the bargaining inefficiency $1-a_{\theta}$. When $c_{\theta}=0$, as is true for the holdout threat, both dispute incidence and duration are invariant to changes in $a_{\theta}$. This is in contrast to the joint cost hypothesis (Kennan 1980; Reder and Neumann 1980), which posits that disputes should be less frequent and shorter when they are more costly. A weakness of the joint cost hypothesis is that it fails to identify the benefits of the dispute. Rather, it implicitly assumes that these benefits remain fixed as costs vary. In contrast, our model of wage bargaining explicitly captures both the costs and the benefits of the dispute. We find that the benefit to the firm of a longer dispute (a lower wage) necessarily changes as the bargaining cost $1-a_{\theta}$ varies.

Our third proposition demonstrates that the threat decision critically depends on the current wage.

PROPOSITION 3. If $w_{0}<\widetilde{w}$, the union strikes; if $w_{0} \geq \widetilde{w}$, the union chooses to hold out, where $\widetilde{w}=x_{s}+\left(1-a_{S}\right)\left(m\left(c_{S}\right)+c_{S}\right)\left[1-F\left(m\left(c_{S}\right)\right)\right]-\left(1-a_{H}\right)\left(m(0)[1-F(m(0))]\right.$ and $m\left(c_{\theta}\right)$ maximizes $(1)$.

In fitting the model to the data, we must recognize that in any year some unions choose the strike threat, while other unions choose the holdout threat. This can be accommodated in the model by introducing heterogeneity over the parameter $w_{0}$. (With a sequence of contracts, heterogeneity over $w_{0}$ would arise naturally from past realizations of $v$.) In particular, suppose that $w_{0}$ is drawn from the distribution $G$. Then from Proposition 3, the strike threat is chosen if $w_{0} \leq \tilde{w}$, which occurs with probability $G(\widetilde{w})$; otherwise, the holdout threat is chosen.

\section{The Benchmark Model}

We now turn to an example in which both $v$ and $w_{0}$ are uniformly distributed, so we can explicitly calculate the equilibrium outcome as a function of the parameters. ${ }^{11}$ Our purpose is to determine benchmark values for the parameters such that the equilibrium outcome fits the descriptive statistics of collective bargaining in the U.S. over the last twenty years. We begin by determining the equilibrium

\footnotetext{
${ }^{11}$ We have calculated the equilibrium with other distributions such as the truncated normal and extreme value distributions; the results are similar. The advantage of the uniform distribution is that the equilibrium strategies can be calculated analytically.
} 
with uniform uncertainty.

Proposition 4. In the equilibrium with uniform uncertainty, the union selects the strike threat if $w_{0} \leq \tilde{w}$ where

$$
\begin{gathered}
\tilde{w}=x_{S}+\left(1-a_{S}\right)\left(m\left(c_{S}\right)+c_{S}\right) \frac{h-m\left(c_{S}\right)}{h-\ell}-\left(1-a_{H}\right) m(0) \frac{h-m(0)}{h-\ell}, \\
m\left(c_{\theta}\right)=-c_{\theta}+\frac{1}{4}\left[k+\left(h+c_{\theta}\right)\left(1+\left(h+c_{\theta}\right) / k\right)\right],
\end{gathered}
$$

and

$$
\left.k=\left[4 \sqrt{\left(\ell+c_{\theta}\right)^{3}\left[\left(h+c_{\theta}\right)^{3}+4\left(\ell+c_{\theta}\right)^{3}\right.}\right]+\left(h+c_{\theta}\right)^{3}+8\left(\ell+c_{\theta}\right)^{3}\right]^{1 / 3} .
$$

The union's initial offer $w_{\theta}\left(m\left(c_{\theta}\right)\right)$ is accepted by the firm if $v \geq m$ and otherwise rejected.

Once the preferred threat and the initial offer are determined, it is a simple matter to calculate other features of the equilibrium and show how the equilibrium outcome changes as we vary the parameters of the model. We assume that $v$ is uniform on $1 \pm \mu$, so that $v$ has a mean of 1 and a variance of $\mu^{2} / 3$. Thus, increasing $\mu$ represents a mean-preserving spread of the distribution of $v$. We refer to $\mu$ as the level of uncertainty for $\mu \in[0,1]$. For calculations that depend on $r$ and $T$, we assume an interest rate of $10 \%$ and a contract length of 2.7 years, the mean contract length in our sample. We assume a $25 \%$ decline in productivity during a strike $\left(a_{S}=75 \%\right)$. This is roughly consistent with a union wage differential of $14 \%$ (Lewis 1986), since the union gets a premium of about one-half of the inefficiency it can impose on the firm. We suppose that $w_{0}$ is uniformly distributed on $W_{0} \pm \lambda$. We will choose $W_{0}$ to approximate the empirical strike incidence, assuming $\lambda=0.05$.

Table 1 shows dispute incidence and duration for large bargaining units (>1000 workers) in the U.S., based on 5,002 contract negotiations from 1970 to $1989 .{ }^{12}$ We will use this data to determine benchmark levels for the model parameters. A feature of the model is that the holdout duration depends only on the level of uncertainty $\mu$. A holdout duration of 32 days implies that $\mu=0.07$. Given $\mu$, strike duration depends only on $c_{S}$. To fit a strike duration of 32 days, we set $c_{S}=0 .{ }^{13}$ McConnell (1989) using U.S. data estimates a $3 \%$ decline in wages per 100 days of strike. ${ }^{14}$ For the model to generate this $3 \%$ wage decline we need to set $x_{S}=0.35$. To fit the observed strike incidence of $10 \%$, we set $W_{0}=0.48$, so $w_{0}$ ranges from 0.43 to 0.53 with $\lambda=0.05$. Finally, we set $a_{H}=96 \%$ to yield a nominal wage change conditional on agreement of $5.3 \%$, the observed value in McConnell's data. With the parameters set at these benchmark levels, the implied dispute incidence is $52 \%$. The dispute incidence observed in the data is $57 \%$. We will use this benchmark in the next section to examine the sensitivity of the equilibrium to changes in the model parameters.

${ }^{12}$ See McConnell (1989) and Cramton and Tracy (1992).

${ }^{13}$ We use a strike duration of 32 rather than 27 days to account for the period of holdout that sometimes proceeds a strike. The median holdout duration prior to a strike is 26 days. When we extend the model to allow for strike deadlines (Cramton and Tracy 1993), we find that the hazard rate during the holdout before the strike is about 1/5th the hazard rate after the strike. Hence, a holdout duration of 26 days before a strike is roughly equivalent to 5 days of strike.

${ }^{14}$ In contrast, Card (1990b) using Canadian data finds no relationship between wages and strike duration. 
Table 1

Dispute Activity in the United States

1970-1989

\begin{tabular}{lcc}
\hline & $\begin{array}{c}\text { Incidence } \\
(\%)\end{array}$ & $\begin{array}{c}\text { Duration } \\
\text { (Median Days) }\end{array}$ \\
\hline Holdout & 47 & 32 \\
Strike & 10 & 27 \\
Dispute & 57 & 37 \\
\hline
\end{tabular}

NOTE. - Holdout $=$ contract is ratified without a strike more than 1 day after contract expiration. Strike $=$ strike occurs before contract signed. Dispute $=$ either strike or holdout occurs before contract is signed. Strike duration does not include holdout day prior to the strike. Dispute duration includes holdout days prior to the strike.

We define any contract ratified without a strike more than one day after the contract expiration as a holdout. This definition allows one day for ratifying a contract signed on the contract expiration date. Neither the benchmark nor our results are significantly affected by requiring a longer leadtime (say 3 to 6 days) before identifying a holdout. Indeed, as shown in Table 2, with a longer leadtime our model fits the data more closely. Increasing the minimum number of days before a negotiation is classified as a holdout has the effect of decreasing the actual holdout and dispute incidences, and increasing the actual holdout and dispute durations.

Table 2

Observed and Estimated Dispute Activity with Alternative Definitions of Holdout

\begin{tabular}{|c|c|c|c|c|c|c|c|c|c|c|c|}
\hline \multirow{3}{*}{$\begin{array}{l}\text { Minimum } \\
\text { Days } \\
\text { Needed } \\
\text { to be a } \\
\text { Holdout }\end{array}$} & \multicolumn{4}{|c|}{ Incidence $(\%)$} & \multicolumn{4}{|c|}{ Median Duration (Days) } & \multirow{2}{*}{\multicolumn{3}{|c|}{$\begin{array}{l}\text { Estimated } \\
\text { Parameters }\end{array}$}} \\
\hline & \multicolumn{2}{|c|}{ Holdout } & \multicolumn{2}{|c|}{ Dispute } & \multicolumn{2}{|c|}{ Holdout } & \multicolumn{2}{|c|}{ Dispute } & & & \\
\hline & $\begin{array}{c}\text { Ob- } \\
\text { served }\end{array}$ & $\begin{array}{c}\text { Esti- } \\
\text { mated }\end{array}$ & $\begin{array}{c}\text { Ob- } \\
\text { served }\end{array}$ & $\begin{array}{c}\text { Esti- } \\
\text { mated }\end{array}$ & $\begin{array}{c}\text { Ob- } \\
\text { served }\end{array}$ & $\begin{array}{c}\text { Esti- } \\
\text { mated }\end{array}$ & $\begin{array}{c}\text { Ob- } \\
\text { served }\end{array}$ & $\begin{array}{c}\text { Esti- } \\
\text { mated }\end{array}$ & $c_{S}$ & $\mu$ & $W_{0}$ \\
\hline 2 & 47 & 41 & 57 & 52 & 32 & 32 & 37 & 32 & .00 & .07 & .48 \\
\hline 3 & 45 & 42 & 53 & 52 & 36 & 36 & 39 & 35 & .12 & .08 & .49 \\
\hline 4 & 43 & 42 & 53 & 52 & 38 & 38 & 41 & 37 & .18 & .08 & .50 \\
\hline 5 & 42 & 42 & 52 & 52 & 40 & 40 & 43 & 38 & .24 & .09 & .51 \\
\hline 6 & 40 & 42 & 51 & 52 & 42 & 42 & 44 & 40 & .30 & .09 & .51 \\
\hline
\end{tabular}

Note.-Benchmark is in italic type. Parameters are defined in text.

\section{Sensitivity of the Equilibrium to Changes in the Model Parameters}

Table 3 displays the elasticity of the equilibrium outcomes with respect to each of the model parameters. The first row, labeled $x$, gives the parameter values at the benchmark. The first column, labeled $y$, gives the equilibrium outcome at the benchmark in terms of empirical observables (incidence, duration, settlement rate, wage change, and wage decline) and welfare measures (union share, firm share, and the loss caused by dispute activity). Duration is the median duration in days. The settlement rate is the initial hazard rate (i.e., the hazard rate at the beginning of the dispute) from the indicated threat to settlement in percent per week. The wage change is the mean wage change conditional on the indicated event. For example, conditional on immediate agreement, the nominal wage increases on average by $5.3 \%$. The wage decline is the mean wage decline per 100 days duration of the indicated threat. Each cell 
of the table gives the elasticity of the outcome $y$ with respect to the parameter $x$, i.e., $(d y / d x)(x / y)$. Elasticities that are exactly 0 are left blank.

The most prominent feature of the table is how sensitive the composition of disputes is to changes in the parameters. The fraction of negotiations in which the union prefers the strike threat is $20 \%$ in the benchmark, but this is highly elastic to changes in the holdout threat $\left(a_{H}\right.$ and $\left.W_{0}\right)$ or in the strike threat $\left(a_{S}, x_{S}\right.$, and $\left.b_{S}\right)$. This is intuitive. As the relative attractiveness of the strike threat improves (an increase in $a_{H}, x_{S}$, or $b_{S}$, or a decrease in $a_{S}$ and $W_{0}$ ), the composition of disputes shifts in favor of strikes. This shift in the chosen threat causes holdout and strike incidences to vary in opposite directions, as exhibited by the large elasticities for strike and holdout incidences and the 0.0 elasticities for dispute incidence. Indeed, changes in holdout and strike incidences are almost entirely accounted for by shifts in the composition of disputes. The elasticity of dispute incidence is negligible with respect to all the model parameters, except $\mu$ for which the elasticity is 0.04 . Dispute incidence is only directly affected by changes in uncertainty. In contrast to holdout and strike incidences, holdout and strike durations are insensitive to changes in the threat, but are significantly influenced by the amount of uncertainty.

These elasticity results have implications for the time-series data on contract negotiations. We should expect to see: (1) holdout and strike incidences moving in opposite directions, (2) holdout and strike durations moving in the same direction, and (3) dispute incidence varying less than holdout or strike incidences. The basic time series properties in our data are given in Table 4, which presents dispute incidence and duration by year. In $65 \%$ of the years, an above (below) average holdout incidence was coupled with a below (above) average strike incidence. In $60 \%$ of the years, an above (below) average holdout duration was coupled with an above (below) average strike duration. The standard deviation of dispute incidence is roughly one-half that of the holdout and strike incidences. Regressing the log strike incidence on the log dispute incidence and log dispute composition indicates that at most $14 \%$ of the variance in strike incidence across years is accounted for by the variance in dispute incidence. The scaled dispute incidence, shown in Figure 2, is roughly constant from 1970 to 1982 and then increases through the rest of the decade (incidence for 1970 is not shown in the figure, because of the small number of contracts in that year). In contrast, the strike incidence has wide fluctuations, ranging from $4 \%$ to $16 \%$. 
Table 3

Elasticity of Equilibrium Outcomes with Respect to Model Parameters

\begin{tabular}{|c|c|c|c|c|c|c|c|c|}
\hline & & \multicolumn{7}{|c|}{ Parameters } \\
\hline & $x=$ & $96 \%$ & $75 \%$ & 0.35 & 0.35 & 0.48 & 0.05 & 0.07 \\
\hline$y$ & Outcomes & $a_{H}$ & $a_{S}$ & $x_{S}$ & $b_{S}$ & $W_{0}$ & $\lambda$ & $\mu$ \\
\hline $20 \%$ & Strike Threat & & & & & & & \\
\hline $\begin{array}{l}41 \% \\
10 \% \\
52 \%\end{array}$ & $\begin{array}{l}\text { Incidence: } \\
\text { Holdout } \\
\text { Strike } \\
\text { Dispute }\end{array}$ & $\begin{array}{l}-5.8 \\
23.0\end{array}$ & $\begin{array}{r}4.5 \\
-18.1\end{array}$ & $\begin{array}{r}-2.2 \\
8.8 \\
0.01\end{array}$ & $\begin{array}{r}-2.2 \\
8.7 \\
-0.01\end{array}$ & $\begin{array}{r}6.0 \\
-24.0\end{array}$ & $\begin{array}{r}-0.4 \\
1.5\end{array}$ & $\begin{array}{r}0.1 \\
-0.1 \\
0.04\end{array}$ \\
\hline $\begin{array}{l}32 \\
32 \\
32\end{array}$ & $\begin{array}{l}\text { Duration: } \\
\text { Holdout } \\
\text { Strike } \\
\text { Dispute }\end{array}$ & & & $\begin{array}{l}1.5 \\
0.3\end{array}$ & $\begin{array}{l}-1.5 \\
-0.3\end{array}$ & & & $\begin{array}{l}1.0 \\
1.0 \\
1.0\end{array}$ \\
\hline $\begin{array}{l}11.0 \% \\
11.0 \% \\
11.0 \%\end{array}$ & $\begin{array}{l}\text { Settlement Rate: } \\
\text { Holdout } \\
\text { Strike } \\
\text { Dispute }\end{array}$ & & & $\begin{array}{l}-1.5 \\
-0.3\end{array}$ & $\begin{array}{l}1.5 \\
0.3\end{array}$ & & & $\begin{array}{l}-1.0 \\
-1.0 \\
-1.0\end{array}$ \\
\hline $\begin{array}{l}4.4 \% \\
7.2 \% \\
5.3 \%\end{array}$ & $\begin{array}{l}\text { Wage Change: } \\
\text { Holdout } \\
\text { Strike } \\
\text { Dispute }\end{array}$ & $\begin{array}{r}-21.9 \\
-7.7 \\
-14.0\end{array}$ & $\begin{array}{r}0.4 \\
-5.4 \\
-3.8\end{array}$ & $\begin{array}{r}-0.2 \\
2.6 \\
1.8\end{array}$ & $\begin{array}{r}-0.2 \\
2.6 \\
1.8\end{array}$ & $\begin{array}{l}-0.5 \\
-8.3 \\
-5.8\end{array}$ & $\begin{array}{l}0.0 \\
0.9 \\
0.4\end{array}$ & $\begin{array}{r}0.0 \\
-0.1 \\
0.0\end{array}$ \\
\hline $\begin{array}{l}0.5 \% \\
3.0 \% \\
1.0 \%\end{array}$ & $\begin{array}{l}\text { Wage Decline: } \\
\text { Holdout } \\
\text { Strike } \\
\text { Dispute }\end{array}$ & $\begin{array}{r}-21.0 \\
3.3\end{array}$ & $\begin{array}{r}0.4 \\
-2.2 \\
-10.3\end{array}$ & $\begin{array}{r}-0.2 \\
-1.8 \\
3.3\end{array}$ & $\begin{array}{r}-0.2 \\
1.0 \\
5.0\end{array}$ & $\begin{array}{r}-0.4 \\
-12.3\end{array}$ & $\begin{array}{l}0.0 \\
0.7\end{array}$ & $\begin{array}{r}0.0 \\
0.0 \\
-0.1\end{array}$ \\
\hline $\begin{array}{l}51 \% \\
47 \% \\
51 \%\end{array}$ & $\begin{array}{l}\text { Union's Share: } \\
\text { Holdout } \\
\text { Strike } \\
\text { Dispute }\end{array}$ & $\begin{array}{l}-0.4 \\
-0.7\end{array}$ & $\begin{array}{l}-0.4 \\
-0.8 \\
-0.1\end{array}$ & $\begin{array}{l}0.2 \\
0.4 \\
0.1\end{array}$ & $\begin{array}{l}0.2 \\
0.4 \\
0.1\end{array}$ & $\begin{array}{l}0.5 \\
0.8\end{array}$ & $\begin{array}{l}0.0 \\
0.0\end{array}$ & $\begin{array}{l}0.0 \\
0.0 \\
0.0\end{array}$ \\
\hline $\begin{array}{l}49 \% \\
52 \% \\
49 \%\end{array}$ & $\begin{array}{l}\text { Firm's Share: } \\
\text { Holdout } \\
\text { Strike } \\
\text { Dispute }\end{array}$ & $\begin{array}{l}0.5 \\
0.7\end{array}$ & $\begin{array}{l}0.4 \\
0.7 \\
0.2\end{array}$ & $\begin{array}{l}-0.2 \\
-0.3 \\
-0.1\end{array}$ & $\begin{array}{l}-0.2 \\
-0.3 \\
-0.1\end{array}$ & $\begin{array}{l}-0.5 \\
-0.7\end{array}$ & $\begin{array}{l}-0.1 \\
0.0\end{array}$ & $\begin{array}{l}0.0 \\
0.0 \\
0.0\end{array}$ \\
\hline $\begin{array}{l}0.08 \% \\
0.45 \% \\
0.16 \%\end{array}$ & $\begin{array}{l}\text { Loss: } \\
\text { Holdout } \\
\text { Strike } \\
\text { Dispute }\end{array}$ & $\begin{array}{r}-21.5 \\
2.2\end{array}$ & $\begin{array}{r}-3.0 \\
-10.4\end{array}$ & $\begin{array}{l}0.0 \\
4.2\end{array}$ & $\begin{array}{l}0.0 \\
4.2\end{array}$ & -11.5 & 0.7 & $\begin{array}{l}1.0 \\
1.0 \\
0.9\end{array}$ \\
\hline
\end{tabular}

NOTE. $-v$ is uniform on $1 \pm \mu ; w_{0}$ is uniform on $W_{0} \pm \lambda$. First row, $x$, gives the parameter values at the benchmark. First column, $y$, gives the equilibrium outcome at the benchmark. Each cell of table gives elasticity of outcome $y$ with respect to parameter $x=$ $(d y / d x)(x / y)$. If the elasticity is 0 , the cell is left blank. Duration $=$ median duration (days). Settlement Rate $=$ initial settlement rate $(\% /$ week $)$. Wage Change $=$ mean wage change conditional on event $(\%)$. Wage Decline $=$ mean wage decline during threat $(\% / 100$ days).

Another interesting feature of the data is that the mean durations are all much longer than the median durations. This is consistent with the model's high elasticity of duration with respect to $\mu$. Since in the model duration increases rapidly as uncertainty increases, heterogeneity across firms in the level of uncertainty implies that mean durations will exceed median durations. 
Table 4

Dispute Incidence and Duration by Year

\begin{tabular}{|c|c|c|c|c|c|c|c|c|}
\hline \multirow[b]{3}{*}{ Year } & \multirow{3}{*}{$\begin{array}{c}\text { Number } \\
\text { of } \\
\text { Contracts }\end{array}$} & & & & \multicolumn{4}{|c|}{ Duration (Days) } \\
\hline & & \multicolumn{3}{|c|}{ Incidence $(\%)$} & \multirow{2}{*}{\multicolumn{2}{|c|}{$\begin{array}{c}\text { Strike } \\
\text { without } \\
\text { Holdout }\end{array}$}} & \multirow{2}{*}{$\begin{array}{c}\text { Strike } \\
\text { with } \\
\text { Holdout }\end{array}$} & \multirow[b]{2}{*}{ Dispute } \\
\hline & & Holdout & Strike & Dispute & & & & \\
\hline 1970 & 19 & 32 & 21 & 53 & 103 & 37 & 103 & 103 \\
\hline 1971 & 152 & 36 & 13 & 49 & 95 & 33 & 129 & 104 \\
\hline 1972 & 115 & 46 & 9 & 55 & 94 & 12 & 81 & 92 \\
\hline 1973 & 238 & 37 & 12 & 49 & 48 & 20 & 62 & 51 \\
\hline 1974 & 324 & 42 & 14 & 56 & 26 & 24 & 37 & 29 \\
\hline 1975 & 244 & 41 & 9 & 49 & 23 & 47 & 52 & 28 \\
\hline 1976 & 279 & 42 & 16 & 57 & 21 & 29 & 60 & 32 \\
\hline 1977 & 362 & 37 & 11 & 49 & 38 & 35 & 50 & 41 \\
\hline 1978 & 211 & 39 & 16 & 55 & 22 & 29 & 49 & 30 \\
\hline 1979 & 278 & 36 & 13 & 49 & 42 & 33 & 51 & 44 \\
\hline 1980 & 349 & 35 & 8 & 43 & 19 & 26 & 68 & 29 \\
\hline 1981 & 223 & 45 & 8 & 53 & 23 & 19 & 39 & 26 \\
\hline 1982 & 279 & 46 & 7 & 53 & 30 & 26 & 39 & 31 \\
\hline 1983 & 362 & 52 & 8 & 60 & 35 & 42 & 65 & 39 \\
\hline 1984 & 266 & 52 & 10 & 62 & 28 & 16 & 46 & 31 \\
\hline 1985 & 258 & 56 & 11 & 67 & 36 & 24 & 46 & 38 \\
\hline 1986 & 317 & 58 & 13 & 71 & 27 & 27 & 43 & 30 \\
\hline 1987 & 221 & 67 & 8 & 75 & 41 & 15 & 40 & 41 \\
\hline 1988 & 238 & 65 & 9 & 74 & 24 & 31 & 84 & 31 \\
\hline 1989 & 249 & 65 & 4 & 69 & 36 & 38 & 52 & 37 \\
\hline $1970-79$ & 2,222 & 39 & 13 & 52 & 37 & 29 & 57 & 42 \\
\hline 1980-89 & 2,780 & 53 & 9 & 62 & 30 & 26 & 50 & 33 \\
\hline 1970-89 & 5,002 & 47 & 10 & 57 & 32 & 27 & 53 & 37 \\
\hline
\end{tabular}

NOTE.-Duration $=$ median duration $($ days); holdout $=$ contract is signed without strike more than 1 day after contract expiration; strike = strike occurs before contract is signed; dispute $=$ either strike or holdout occurs before contract is signed; strike without holdout $=$ strike duration in days, not including prior holdout; and strike with holdout $=$ strike duration in days, including prior holdout.

The model predicts that the wage change conditional on a strike should be larger than the wage change conditional on a holdout. This is because the union only selects the strike threat if the higher costs associated with a strike are made up for by a higher wage. The difference between the wage change given a strike and given a holdout grows as the strike threat becomes more attractive (an increase in $x_{S}, b_{S}$, or a decrease in $\left.a_{S}, W_{0}\right)$. The wage change given immediate agreement must be higher than the wage change given a holdout, since immediate agreement implies a nonexercised strike threat or a nonexercised holdout threat, both of which yield a higher wage than an exercised holdout threat. However, the wage change given agreement can be either above or below the wage change given a strike, depending on how frequently the strike threat is chosen. If the strike threat is chosen infrequently, as in the benchmark, then the wage change given agreement will be below the wage change given a strike. In this case, the wage change given a strike is greater than the wage change given either an immediate agreement or a holdout. Card (1990b), Lacroix (1986), McConnell (1989), and Riddell (1980) estimate micro wage equations using contract data. They find a positive coefficient on a strike indicator variable. This effect, however, is rarely significant and changes sign in some specifications. 


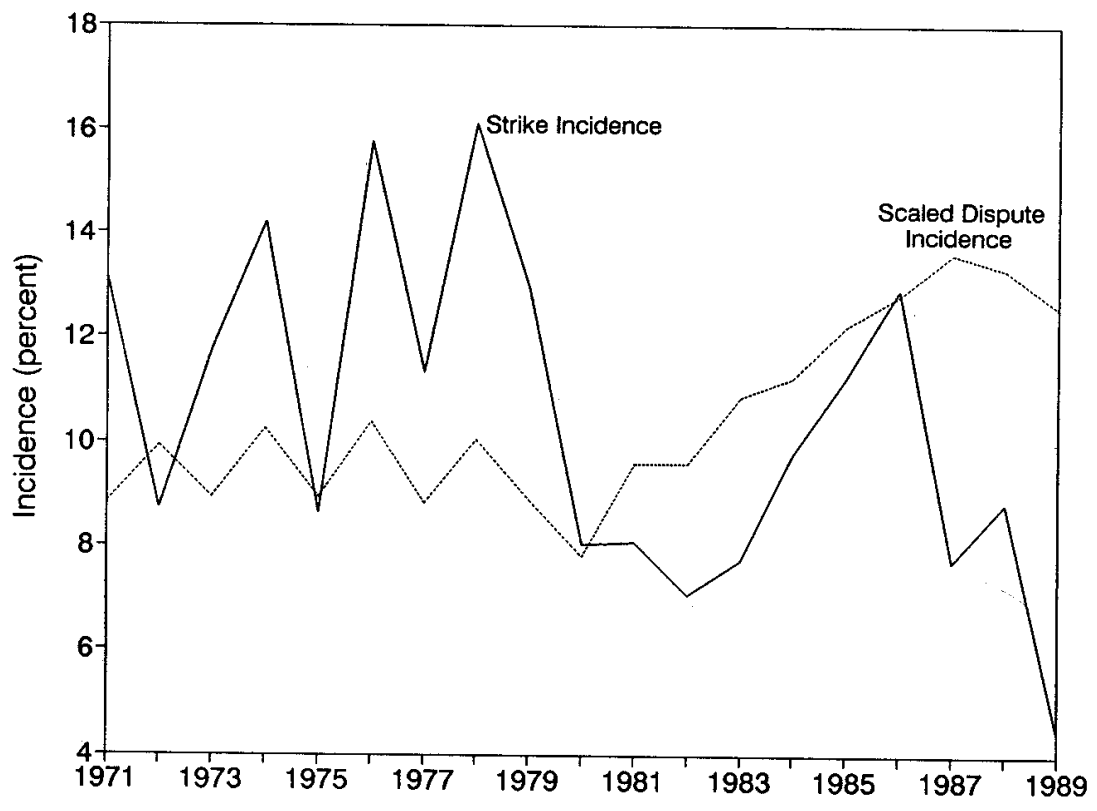

FIG. 2.- Strike and dispute incidence by year

Card (1990b) and McConnell (1989) estimate the slope of the wage/strike duration concession function as a test of the asymmetric information bargaining model. This is potentially problematic for two reasons. First, a downward sloping concession function is implied by only a subset of the bargaining models. When the firm is uncertain about the union's preferences, then the concession function can be upward sloping. Second, even when a downward slope is implied by the theory, the magnitude of the slope can be small and therefore difficult to estimate with much precision. This is especially a problem if strike costs increase over time (Cramton and Tracy 1993). The rate at which wages decline during a threat depends primarily on the inefficiency of the threat. Hence, the wage decline during a holdout should be less than the wage decline during a strike. In addition, the wage decline during a strike will be small if strike inefficiencies are small $\left(a_{S}\right.$ large) or if what the union gets during a strike is large relative to what the firm pays out $\left(-c_{S}\right.$ large).

\section{Empirical Specification of a Bargaining Model}

The elasticities for dispute and strike incidence derived from the benchmark model suggest some empirical regularities that should be present in the micro data. Dispute incidence should be driven by uncertainty. Strike incidence should be driven by shifts in the composition of disputes between holdout and strike. This is the key result from introducing the union's threat choice into the model. In this section, we discuss the empirical specification we use to test these implications.

An inherently difficult parameter to proxy is the level of uncertainty over the firm's willingness to pay. As in Tracy (1987), we use the standard deviation of the firm's stock return adjusted for the overall returns in the market. Specifically, we regress the firm's stock return on the market return using a year of daily trading data ending three months before the contract expiration. The residuals from this regression, the "excess returns," capture firm-specific events that are capitalized into the stock price. Tracy (1987) found that bargaining outcomes were more closely related to the variability in a firm's excess returns than variability in the firm's overall stock returns. This variable has the drawback that it reduces the sample size, since stock prices are available for only $60 \%$ of our contract negotiations. However, we feel that this loss of data is justified by the need for a firm-specific uncertainty measure.

Gramm, Hendricks, and Kahn (1988) use the dispersion in inflation forecasts contained in the Livingston Survey as a measure of inflation uncertainty. They show that strike incidence in their data is higher in periods of greater uncertainty over consumer prices. Our model focuses on the role of information asymmetries between the firm and the union, and does not deal with issues of common 
uncertainty over macro variables. As such, the model does not provide any predictions about the role of inflation uncertainty and dispute activity. However, for the purpose of comparison with their findings, we report results based on a GARCH estimate of inflation uncertainty. We fit the following Garch $(1,1)$ specification using quarterly inflation data from the second quarter of 1947 to the first quarter of 1991:

$$
\pi_{t}=\beta_{0}+\beta_{1} \pi_{t-1}+\beta_{2} \pi_{t-2}+\beta_{3} \pi_{t-3}+\beta_{4} \pi_{t-4}+\varepsilon_{t},
$$

where

$$
\varepsilon_{t} \sim N\left(0, \sigma_{t}^{2}\right), \quad \sigma_{t}^{2}=\alpha_{0}+\alpha_{1} \sigma_{t-1}^{2}+\gamma \varepsilon_{t-1} .
$$

We use the estimated conditional standard deviation, $\hat{\sigma}_{t}$, as our estimate of the inflation uncertainty at time $t$. Figure 3 compares our GARCH uncertainty estimate to the estimate based on the Livingston Survey for the period covered by their study. The two estimates have a similar time series pattern; the correlation between the two estimates is 0.71 .

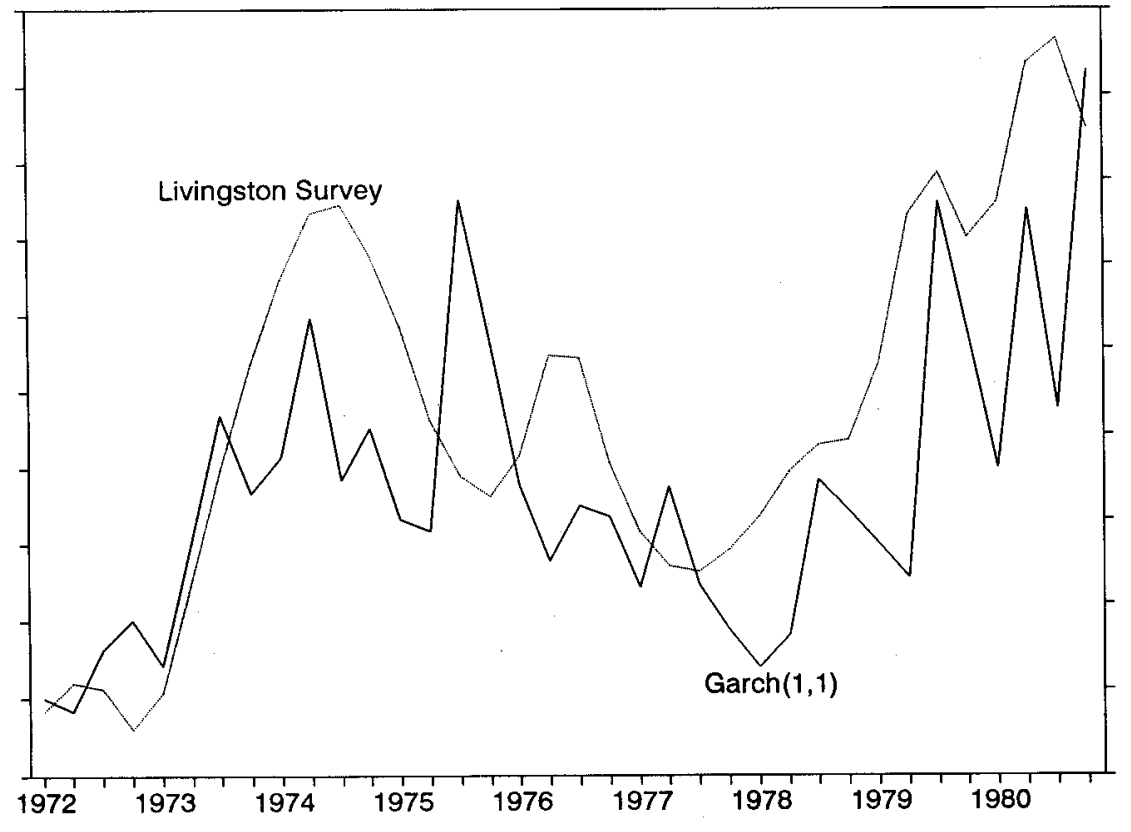

FIG. 3,--Inflation uncertainty: Livingston Survey versus GARCH estimates

Our model suggests that dispute composition will be influenced by prevailing conditions in the labor markets. We develop several indicators of industry and local employment conditions by using the U.S. Bureau of Labor Statistics (BLS) industry and state employment data. We assume that the log quarterly employment can be represented by a quadratic time trend with quarterly dummy variables to capture seasonality effects. In addition, we assume the error process is autoregressive with an innovation that is conditionally heteroscedastic. For each three-digit industry and for each state we fit the following timeseries model: ${ }^{15}$

\footnotetext{
${ }^{15}$ Our estimates were computed using a two step procedure. First, we used SAS to estimate the autoregressive regression equation assuming homoscedastic error variances and to transform the data to remove the serial correlation. We then used TSP to estimate the GARCH regression model.
} 


$$
\log E_{i t}=\beta_{i 0}+\beta_{i 1} t+\beta_{i 2} t^{2}+\sum_{j=1}^{3} \delta_{i j} Q_{j}+u_{i t},
$$

where

$$
\begin{gathered}
u_{i t}=\sum_{j=1}^{k} \rho_{j} u_{i t-k}+\varepsilon_{i t}, \\
\varepsilon_{i t} \sim N\left(0, \sigma_{i t}^{2}\right),
\end{gathered}
$$

and

$$
\sigma_{i t}^{2}=\alpha_{i 0}+\sum_{j=1}^{p} \alpha_{i j} \sigma_{i t-j}^{2}+\sum_{j=1}^{q} \gamma_{i j} \varepsilon_{i t-j}^{2}
$$

We fit the most parsimonious version of this model to each industry and state employment series.

Long-run shifts in the composition of the labor force across industries and regions are proxied by the estimated employment growth rates. Contemporaneous conditions in the relevant labor market are measured by the predicted employment residuals. Since workers on strike may not be counted in the employment figures, we use the predicted rather than the actual employment residual for the quarter that the contract expired. We also include the inverse of the prime age male unemployment rate as a measure of aggregate labor market conditions.

The benchmark elasticities suggest that the real wage under the prior contract should be an important determinant of the composition of disputes. Constructing wage profiles for the contracts in our sample is a difficult task. The BLS reports wage changes for each contract in issues of the Current Wage Developments (CWD). The data from 1970 to 1981 were supplied to us by Sheena McConnell. We coded the data from 1982 to present. The data were then edited for missing or inconsistent payments. The most common situation involved missing cost-of-living adjustment (COLA) payments. We imputed all missing COLA payments. When we had information on the structure of the COLA, we used this to carry out the imputation. In other cases, we regressed the observed COLA payments against the relevant price changes to estimate a linear approximation to the COLA structure. ${ }^{16}$ For those bargaining units that still had missing wage change information, we selected the longest span of contracts with complete wage coverage to include in our sample.

To construct a wage profile for a bargaining unit, we need a base wage at a point in time. We merged in base wage information from data collected by the Bureau of National Affairs (BNA).Starting from the effective date of the base wage, we work backwards in time using the wage change information to infer the base wage at the start of the first contract we observe for that bargaining unit. ${ }^{17}$ We then work forwards calculating the actual and base wage for each month covered by the contracts for that bargaining unit. For many bargaining units, we observe more than one base wage from the BNA. In these cases, we construct a separate wage profile for each base wage, and then average the profiles to form a summary profile. For those bargaining units without a base wage from the BNA, we use the BLS December average wage for that bargaining unit's four digit industry classification for each year that

\footnotetext{
${ }^{16}$ For a subset of our contracts, we were able to impute zero COLAs using correspondence between Wayne Vroman and the BLS that listed missing COLA payments that were nonpayments due to caps or triggers.

${ }^{17}$ The algorithm takes into account the fact that COLA payments typically are not rolled into the base wage until the end of a contract. Some wage concessions take the form of only rolling in a portion of the COLA float at the end of the contract. We account for this whenever it is reported in CWD.
} 
contracts are in effect.

The model predicts that dispute activity is a function of the union's relative uncertainty over its value added under a labor contract. This value added will be influenced by the presence of economic rents in the industry. Holding constant the variability in the economic rents, lowering the general level of rents will add to the degree of relative uncertainty. Increased international competition through the opening up of product markets is one force that will compete away economic rents. We control for the impact of growing international competition on bargaining by using time-series data on the magnitude of imports. Import penetration data were developed by Abowd (1991) and are discussed in Abowd and Freeman (1991). The import penetration ratio is defined to be the import Standard Industrial Classification -(SIC)based value of imports divided by the comparable value of domestic product shipments plus the value of imports. Abowd's series are disaggregated to the four digit SIC classifications and run from 1958 to 1987. We extrapolate the data to 1989.

Dispute activity may also be influenced by the structure of unionization in an industry. The nature of unionism in the industry can affect the relative inefficiency imposed on the firm during a strike or a holdout. We model the structure of unionization in an industry as a function of the union density in the industry and the degree of concentration in the union membership across different unions. Firms in highly unionized industries are more likely themselves to be highly unionized. This limits the ability of the firm to offset any inefficiencies imposed by a bargaining unit at one plant through shifting production to its other plants. Industries with a high concentration of union membership may be more prone to union practices of pattern bargaining. Pattern bargaining should lead to lower overall dispute rates, because the union can target the dispute against a single firm. Assuming private information is correlated among the firms in the pattern, pattern bargaining economizes on disputes.

Following Abowd and Tracy (1989), we adjust our measures of industry unionization rates to reflect the implicit labor content in imported goods. By definition, this labor content is protected from the threat of unionization by U.S. labor unions. The adjusted union density is defined to be the unadjusted union density multiplied by one minus the import penetration ratio. The unadjusted union densities are derived from the collective bargaining agreements (see Bronars, Deere, and Tracy (1993) for a description of the methodology). We use a Herfindahl index of individual union coverage rates to control for the degree of concentration of union membership in an industry.

The final two variables that we include in our empirical specifications are the size of the bargaining unit and the capital intensity of the firm. Although our data are restricted to bargaining units of at least a thousand workers, there is considerable variation in size across bargaining units. Large bargaining units may be better positioned to impose higher inefficiencies on a firm in a strike threat. One possible reason is that it becomes more difficult for the firm to find sufficient numbers of temporary replacements. Similarly, the inefficiency during a strike may be less in firms that employ a highly capital intensive method of production. To the extent that capital intensity is related to the degree of automation in the production process, managers can step in during a strike to keep the plant running. We measure the capital intensity using the current ratio of capital to labor as reported in Compustat.

\section{Determinants of Dispute Incidence and Composition}

We estimate three logit models: (1) the probability of a dispute given a contract negotiation, (2) the probability of a strike given a dispute, and (3) the probability of a strike given a contract negotiation. We standardize the continuous right-hand-side variables to have zero mean and unit standard deviation to facilitate comparing magnitudes across different variables. Summary statistics on the unstandardized data are given in Table 5. Tables 6 and 7 report the marginal effects implied by logit coefficients for the dispute incidence and dispute composition. The marginal effects measure the change in the relevant probability from a one standard deviation change in the underlying control variables. We give results for our basic specification with and without controlling for two-digit industry fixed effects, and estimated separately for the pre and post 1981 time period. We will discuss the pre and post 1981 results in the next section. The results on strike incidence are given in Table 8 to allow comparison with earlier studies. 
Table 5

Summary Statistics

\begin{tabular}{|c|c|c|c|c|}
\hline Variable & Mean & $\begin{array}{l}\text { Standard } \\
\text { Deviation }\end{array}$ & Min & $\operatorname{Max}$ \\
\hline Dispute Incidence & 0.54 & & & \\
\hline Strike Incidence & 0.16 & & & \\
\hline Size of Bargaining Unit ( 1,000 workers) & 5.98 & 27.42 & 0.74 & 462 \\
\hline Capital/Labor $(\$ 1,000 /$ worker $)$ & 0.07 & 0.45 & 0.002 & 7.77 \\
\hline State Employment Growth Rate (\%) & 0.53 & 0.20 & 0.16 & 1.29 \\
\hline Industry Employment Growth Rate (\%) & -0.14 & 0.44 & -1.74 & 2.11 \\
\hline State Predicted Employment Residual (\%) & 0.47 & 3.82 & -10.45 & 15.08 \\
\hline $\begin{array}{l}\text { Industry Predicted Employment Residual } \\
(\%)\end{array}$ & -0.02 & 8.56 & -31.66 & 62.27 \\
\hline $\begin{array}{l}\text { Inverse Prime Age Male Unemployment } \\
\text { Rate }\end{array}$ & 0.18 & 0.05 & 0.10 & 0.33 \\
\hline Inflation Uncertainty & 0.27 & 0.11 & 0.09 & 0.51 \\
\hline Stock Price Uncertainty & 0.02 & 0.01 & 0.005 & 0.05 \\
\hline Import Penetration Ratio & 0.10 & 0.10 & 0.0 & 0.86 \\
\hline \multicolumn{5}{|l|}{ Import Adjusted Percent of Industry } \\
\hline Unionized & 23.06 & 18.67 & 0.03 & 91.28 \\
\hline Union Concentration & 0.54 & 0.25 & 0.11 & 1.00 \\
\hline \multicolumn{5}{|l|}{ Percent Real Wage Change During Prior } \\
\hline Contract & -4.22 & 7.37 & -37.91 & 38.84 \\
\hline Sample Size & 1,114 & & & \\
\hline
\end{tabular}

We define a "dispute" as any negotiation that involves either a strike of any duration or a holdout of more than one day. This definition is motivated by a pronounced deadline effect around the contract expiration. The settlement rate sharply rises at the contract expiration date and the following day. The settlement rate is $15 \%$ on the contract expiration date and $24 \%$ on the following day. By the second day following the contract expiration, the daily settlement rate falls to $4 \%$ and slowly declines to around $2 \%$ over the next week. By requiring a holdout duration of more than one day, we exclude from our measure of disputes those cases that settled at the contract expiration but were not ratified until the next day. (The settlement date reported by the BLS is the date the new contract is ratified by the union membership.) 
Table 6

Dispute Incidence: Probability of a Dispute Given a Contract Negotiation

\begin{tabular}{|c|c|c|c|c|}
\hline Variable & $\begin{array}{l}1970-89 \\
(1)\end{array}$ & $\begin{array}{l}1970-89 \\
\quad(2)\end{array}$ & $\begin{array}{l}1970-81 \\
(3)\end{array}$ & $\begin{array}{c}1982-89 \\
(4)\end{array}$ \\
\hline Size of Bargaining Unit & $\begin{array}{l}0.278 \\
(3.08)\end{array}$ & $\begin{array}{l}0.331 \\
(3.30)\end{array}$ & $\begin{array}{l}0.225 \\
(1.78)\end{array}$ & $\begin{array}{l}0.285 \\
(2.20)\end{array}$ \\
\hline Capital/Labor & $\begin{array}{l}0.004 \\
(0.28)\end{array}$ & & $\begin{array}{l}-0.416 \\
(1.65)\end{array}$ & $\begin{array}{l}-0.0 \\
(0.03)\end{array}$ \\
\hline \multicolumn{5}{|l|}{ State Employment Growth } \\
\hline Rate & $\begin{array}{l}0.023 \\
(1.54)\end{array}$ & $\begin{array}{l}0.011 \\
(0.67)\end{array}$ & $\begin{array}{l}0.049 \\
(2.16)\end{array}$ & $\begin{array}{l}0.005 \\
(0.27)\end{array}$ \\
\hline \multicolumn{5}{|c|}{ Industry Employment Growth } \\
\hline Rate & $\begin{array}{l}0.012 \\
(0.78)\end{array}$ & $\begin{array}{c}-0.010 \\
(0.52)\end{array}$ & $\begin{array}{l}0.026 \\
(0.96)\end{array}$ & $\begin{array}{l}0.006 \\
(0.31)\end{array}$ \\
\hline \multicolumn{5}{|c|}{ State Predicted Employment } \\
\hline Residual & $\begin{array}{l}0.037 \\
(2.05)\end{array}$ & $\begin{array}{l}0.031 \\
(1.60)\end{array}$ & $\begin{array}{l}0.027 \\
(1.00)\end{array}$ & $\begin{array}{l}0.084 \\
(2.78)\end{array}$ \\
\hline \multicolumn{5}{|l|}{ Industry Predicted } \\
\hline Employment Residual & $\begin{array}{l}0.004 \\
(0.29)\end{array}$ & $\begin{array}{c}-0.008 \\
(0.49)\end{array}$ & $\begin{array}{l}0.019 \\
(0.91)\end{array}$ & $\begin{array}{l}0.005 \\
(0.16)\end{array}$ \\
\hline \multicolumn{5}{|l|}{ Inverse Prime Age Male } \\
\hline Unemployment Rate & $\begin{array}{l}-0.007 \\
(0.40)\end{array}$ & $\begin{array}{r}-0.003 \\
(0.14)\end{array}$ & $\begin{array}{l}0.002 \\
(0.08)\end{array}$ & $\begin{array}{l}-0.004 \\
(0.11)\end{array}$ \\
\hline Inflation Uncertainty & $\begin{array}{l}-0.022 \\
(1.39)\end{array}$ & $\begin{array}{l}-0.022 \\
(1.28)\end{array}$ & $\begin{array}{l}-0.032 \\
(1.24)\end{array}$ & $\begin{array}{l}0.001 \\
(0.04)\end{array}$ \\
\hline Stock Price Uncertainty & $\begin{array}{l}0.015 \\
(0.99)\end{array}$ & $\begin{array}{l}0.013 \\
(0.82)\end{array}$ & $\begin{array}{l}0.040 \\
(2.00)\end{array}$ & $\begin{array}{c}-0.029 \\
(1.23)\end{array}$ \\
\hline Import Penetration Ratio & $\begin{array}{l}0.006 \\
(0.37)\end{array}$ & $\begin{array}{l}-0.015 \\
(0.79)\end{array}$ & $\begin{array}{l}0.035 \\
(1.32)\end{array}$ & $\begin{array}{l}-0.016 \\
(0.78)\end{array}$ \\
\hline \multicolumn{5}{|l|}{ Import Adjusted Percent of } \\
\hline & $(1.39)$ & $(0.33)$ & $(2.40)$ & $(0.00)$ \\
\hline Union Concentration & $\begin{array}{l}-0.001 \\
(0.05)\end{array}$ & $\begin{array}{r}-0.031 \\
(1.58)\end{array}$ & $\begin{array}{l}-0.039 \\
(1.55)\end{array}$ & $\begin{array}{l}0.021 \\
(0.85)\end{array}$ \\
\hline $\begin{array}{l}\text { Percent Real Wage Chang } \\
\text { during Prior Contract }\end{array}$ & $\begin{array}{l}0.046 \\
(2.97)\end{array}$ & $\begin{array}{l}0.045 \\
(2.73)\end{array}$ & $\begin{array}{l}0.049 \\
(2.25)\end{array}$ & $\begin{array}{l}0.007 \\
(0.27)\end{array}$ \\
\hline \multicolumn{5}{|c|}{ Industry Fixed Effects included } \\
\hline Sample Size & 1,212 & 1,212 & 649 & 563 \\
\hline-2 log likelihood & 1,617 & 1,531 & 850 & 744 \\
\hline
\end{tabular}

NOTE.- Standardized logistic marginal effects are reported with $t$-statistics in parentheses.

Despite our efforts to restrict the definition of a dispute to the most likely candidates, some short holdouts may be misclassified as disputes. Misclassifying disputes is a problem in that it will bias the coefficient estimates toward zero. To investigate the possibility of misclassification, we estimate a generalized logistic model. The generalized logistic model includes parameters that represent the probability that a holdout of a specific duration is a dispute. We estimate versions allowing misclassification of holdouts from two to five days in duration. For these short holdouts, the contribution to the likelihood is a weighted average of the likelihood given that the negotiation is classified as a dispute and the likelihood given that the negotiation is classified as a settlement. The weight is estimated as a parameter. In all cases, the data indicate that $100 \%$ of holdouts with short durations should be classified as disputes. Given this finding, we report estimates derived from a standard logistic model. 
Table 7

Dispute Composition: Probability of a Strike Given a Dispute

\begin{tabular}{|c|c|c|c|c|}
\hline Variable & $\begin{array}{l}1970-89 \\
(1)\end{array}$ & $\begin{array}{c}1970-89 \\
(2)\end{array}$ & $\begin{array}{l}1970-81 \\
\text { (3) }\end{array}$ & $\begin{array}{c}1982-89 \\
(4)\end{array}$ \\
\hline Size of Bargaining Unit & $\begin{array}{l}0.004 \\
(0.31)\end{array}$ & $\begin{array}{c}0.0 \\
(0.02)\end{array}$ & $\begin{array}{l}0.001 \\
(0.05)\end{array}$ & $\begin{array}{l}0.014 \\
(0.82)\end{array}$ \\
\hline Capital/Labor & $\begin{array}{l}0.009 \\
(0.53)\end{array}$ & $\begin{array}{l}0.004 \\
(0.32)\end{array}$ & $\begin{array}{l}0.018 \\
(0.05)\end{array}$ & $\begin{array}{l}0.012 \\
(0.92)\end{array}$ \\
\hline \multicolumn{5}{|l|}{ State Employment Growth } \\
\hline Rate & $\begin{array}{l}-0.059 \\
(2.93)\end{array}$ & $\begin{array}{r}-0.028 \\
(1.87)\end{array}$ & $\begin{array}{l}-0.045 \\
(1.56)\end{array}$ & $\begin{array}{r}-0.040 \\
(1.67)\end{array}$ \\
\hline \multicolumn{5}{|c|}{ Industry Employment Growth } \\
\hline Rate & $\begin{array}{l}0.011 \\
(0.54)\end{array}$ & $\begin{array}{l}0.010 \\
(0.66)\end{array}$ & $\begin{array}{l}0.019 \\
(0.58)\end{array}$ & $\begin{array}{l}0.019 \\
(0.84)\end{array}$ \\
\hline \multicolumn{5}{|c|}{ State Predicted Employment } \\
\hline Residual & $\begin{array}{c}-0.006 \\
(0.27)\end{array}$ & $\begin{array}{l}-0.005 \\
(0.31)\end{array}$ & $\begin{array}{r}-0.041 \\
(1.16)\end{array}$ & $\begin{array}{c}-0.002 \\
(0.06)\end{array}$ \\
\hline \multicolumn{5}{|l|}{ Industry Predicted } \\
\hline Employment Residual & $\begin{array}{c}0.023 \\
(1.18)\end{array}$ & $\begin{array}{l}0.007 \\
(0.57)\end{array}$ & $\begin{array}{l}0.074 \\
(2.86)\end{array}$ & $\begin{array}{l}-0.046 \\
(1.49)\end{array}$ \\
\hline \multicolumn{5}{|l|}{ Inverse Prime Age Male } \\
\hline Unemployment Rate & $\begin{array}{l}0.036 \\
(1.65)\end{array}$ & $\begin{array}{l}0.022 \\
(1.47)\end{array}$ & $\begin{array}{l}0.049 \\
(1.82)\end{array}$ & $\begin{array}{l}-0.002 \\
(0.05)\end{array}$ \\
\hline Inflation Uncertainty & $\begin{array}{r}-0.014 \\
(0.68)\end{array}$ & $\begin{array}{c}-0.018 \\
(1.28)\end{array}$ & $\begin{array}{l}-0.055 \\
(1.82)\end{array}$ & $\begin{array}{l}-0.015 \\
(0.61)\end{array}$ \\
\hline Stock Price Uncertainty & $\begin{array}{l}0.024 \\
(1.33)\end{array}$ & $\begin{array}{l}0.012 \\
(0.95)\end{array}$ & $\begin{array}{l}0.025 \\
(1.10)\end{array}$ & $\begin{array}{l}0.015 \\
(0.54)\end{array}$ \\
\hline Import Penetration Ratio & $\begin{array}{l}0.011 \\
(0.50)\end{array}$ & $\begin{array}{l}0.008 \\
(0.52)\end{array}$ & $\begin{array}{l}0.004 \\
(0.13)\end{array}$ & $\begin{array}{l}0.005 \\
(0.19)\end{array}$ \\
\hline \multicolumn{5}{|l|}{ Import Adjusted Percent of } \\
\hline Industry Unionized & $\begin{array}{l}0.041 \\
(2.02)\end{array}$ & $\begin{array}{c}0.020 \\
(1.20)\end{array}$ & $\begin{array}{l}0.056 \\
(2.06)\end{array}$ & $\begin{array}{l}0.016 \\
(0.59)\end{array}$ \\
\hline Union Concentration & $\begin{array}{l}-0.047 \\
(2.08)\end{array}$ & $\begin{array}{r}-0.026 \\
(1.50)\end{array}$ & $\begin{array}{l}-0.086 \\
(2.69)\end{array}$ & $\begin{array}{l}0.001 \\
(0.05)\end{array}$ \\
\hline $\begin{array}{l}\text { Percent Real Wage Chan } \\
\text { during Prior Contract }\end{array}$ & $\begin{array}{l}-0.029 \\
(1.51)\end{array}$ & $\begin{array}{l}-0.027 \\
(1.98)\end{array}$ & $\begin{array}{r}-0.069 \\
(2.78)\end{array}$ & $\begin{array}{l}0.052 \\
(1.85)\end{array}$ \\
\hline \multicolumn{5}{|c|}{ Industry Fixed Effects included } \\
\hline Sample Size & 659 & 659 & 346 & 313 \\
\hline$-2 \log$ likelihood & 763 & 708 & 416 & 321 \\
\hline
\end{tabular}

NOTE.- Standardized logistic marginal effects are reported with $t$-statistics in parentheses.

The model suggests that a useful way to study strike incidence is by separately looking at dispute incidence and the composition of disputes between strikes and holdouts. The model implies low elasticities of dispute incidence associated with all parameters except for the union's uncertainty over the value added from a settlement. To the extent that our stock price uncertainty measure is a good proxy for this source of uncertainty, dispute incidence should be positively related to our firm-specific uncertainty measure. Table 6 gives logistic marginal effects for the probability of a dispute. We find for the full sample period that dispute incidence is higher for firms experiencing more variability in their excess returns. However, this relationship is neither large in magnitude nor precisely measured. A one standard deviation increase in our uncertainty measure is related to about a 1.5 percentage point increase in dispute rates. As we will discuss in detail in the next section, the impact of uncertainty on dispute incidence has changed dramatically between the 1970s and the 1980s. The model's prediction is strongly supported by negotiations carried out before 1982. However, post 1981 there is no evidence of a positive connection between variability in excess returns and disputes. In contrast, we find no evidence of a 
positive association between inflation uncertainty and labor disputes for either the 1970s or the 1980s.

Table 8

Strike Incidence: Probability of a Strike Given a Contract Negotiation

\begin{tabular}{|c|c|c|c|c|}
\hline Variable & $\begin{array}{c}1970-89 \\
\text { (1) }\end{array}$ & $\begin{array}{c}1970-89 \\
(2)\end{array}$ & $\begin{array}{c}1970-81 \\
\text { (3) }\end{array}$ & $\begin{array}{c}1982-89 \\
(4)\end{array}$ \\
\hline Size of Bargaining Unit & $\begin{array}{l}0.010 \\
(1.18)\end{array}$ & $\begin{array}{l}0.004 \\
(0.91)\end{array}$ & $\begin{array}{l}0.005 \\
(0.56)\end{array}$ & $\begin{array}{l}0.016 \\
(1.38)\end{array}$ \\
\hline Capital/Labor & $\begin{array}{l}0.005 \\
(0.52)\end{array}$ & & $\begin{array}{r}-0.087 \\
(0.60)\end{array}$ & $\begin{array}{l}0.005 \\
(0.73)\end{array}$ \\
\hline \multicolumn{5}{|l|}{ State Employment Growth } \\
\hline Rate & $\begin{array}{c}-0.020 \\
(1.82)\end{array}$ & $\begin{array}{c}-0.008 \\
(1.06)\end{array}$ & $\begin{array}{c}-0.008 \\
(0.63)\end{array}$ & $\begin{array}{l}-0.019 \\
(1.42)\end{array}$ \\
\hline \multicolumn{5}{|c|}{ Industry Employment Growth } \\
\hline Rate & $\begin{array}{l}0.010 \\
(0.83)\end{array}$ & $\begin{array}{c}0.0 \\
(0.04)\end{array}$ & $\begin{array}{l}0.017 \\
(1.10)\end{array}$ & $\begin{array}{l}0.016 \\
(0.87)\end{array}$ \\
\hline \multicolumn{5}{|l|}{ State Predicted Employment } \\
\hline Residual & $\begin{array}{l}0.006 \\
(0.48)\end{array}$ & $\begin{array}{l}0.002 \\
(0.20)\end{array}$ & $\begin{array}{l}-0.008 \\
(0.50)\end{array}$ & $\begin{array}{l}0.016 \\
(0.87)\end{array}$ \\
\hline \multicolumn{5}{|l|}{ Industry Predicted } \\
\hline Employment Residual & $\begin{array}{l}0.012 \\
(1.13)\end{array}$ & $\begin{array}{l}0.004 \\
(0.68)\end{array}$ & $\begin{array}{l}0.031 \\
(2.70)\end{array}$ & $\begin{array}{l}-0.026 \\
(1.42)\end{array}$ \\
\hline \multicolumn{5}{|l|}{ Inverse Prime Age Male } \\
\hline Unemployment Rate & $\begin{array}{l}0.020 \\
(1.63)\end{array}$ & $\begin{array}{l}0.012 \\
(1.59)\end{array}$ & $\begin{array}{l}0.025 \\
(1.96)\end{array}$ & $\begin{array}{l}0.001 \\
(0.04)\end{array}$ \\
\hline Inflation Uncertainty & $\begin{array}{l}-0.012 \\
(1.07)\end{array}$ & $\begin{array}{l}-0.009 \\
(1.29)\end{array}$ & $\begin{array}{l}-0.026 \\
(1.80)\end{array}$ & $\begin{array}{l}-0.008 \\
(0.52)\end{array}$ \\
\hline Stock Price Uncertainty & $\begin{array}{l}0.013 \\
(1.35)\end{array}$ & $\begin{array}{l}0.005 \\
(0.76)\end{array}$ & $\begin{array}{l}0.014 \\
(1.36)\end{array}$ & $\begin{array}{l}-0.001 \\
(0.05)\end{array}$ \\
\hline Import Penetration Ratio & $\begin{array}{l}0.007 \\
(0.58)\end{array}$ & $\begin{array}{l}0.001 \\
(0.08)\end{array}$ & $\begin{array}{l}0.009 \\
(0.60)\end{array}$ & $\begin{array}{c}0.0 \\
(0.04)\end{array}$ \\
\hline \multicolumn{5}{|l|}{ Import Adjusted Percent of } \\
\hline Industry Unionized & $\begin{array}{l}0.031 \\
(2.70)\end{array}$ & $\begin{array}{l}0.014 \\
(1.53)\end{array}$ & $\begin{array}{l}0.042 \\
(3.17)\end{array}$ & $\begin{array}{l}0.011 \\
(0.68)\end{array}$ \\
\hline Union Concentration & $\begin{array}{l}-0.024 \\
(1.94)\end{array}$ & $\begin{array}{l}-0.013 \\
(1.43)\end{array}$ & $\begin{array}{l}-0.048 \\
(3.15)\end{array}$ & $\begin{array}{l}0.006 \\
(0.40)\end{array}$ \\
\hline $\begin{array}{l}\text { Percent Real Wage Chang } \\
\text { during Prior Contract }\end{array}$ & $\begin{array}{l}-0.003 \\
(0.25)\end{array}$ & $\begin{array}{l}-0.006 \\
(0.91)\end{array}$ & $\begin{array}{l}-0.016 \\
(1.37)\end{array}$ & $\begin{array}{l}0.031 \\
(1.89)\end{array}$ \\
\hline \multicolumn{5}{|c|}{ Industry Fixed Effects included } \\
\hline $\begin{array}{l}\text { Sample Size } \\
-2 \text { log likelihood }\end{array}$ & $\begin{array}{l}1,212 \\
1,029\end{array}$ & $\begin{array}{c}1,212 \\
983\end{array}$ & $\begin{array}{l}649 \\
596\end{array}$ & $\begin{array}{l}563 \\
410\end{array}$ \\
\hline
\end{tabular}

NOTE.- Standardized logistic marginal effects are reported with $t$-statistics in parentheses.

The largest marginal effect is for the size of the bargaining unit. A one standard deviation increase in the size of the bargaining unit is associated with about a 30 percentage point increase in the likelihood of a dispute. As specifications (3) and (4) indicate, the impact of bargaining unit size on dispute rates has increased from the 1970s to the 1980s.

Two of the remaining variables have a significant relation to dispute activity. We find that disputes are more likely to occur in tight local labor markets. Both higher trend rates of employment growth in the state as well as current employment above trend are associated with higher levels of dispute activity. In addition, a dispute is more likely following a contract where there has been little erosion in the real wage. This effect is robust to the inclusion of industry effects.

A key prediction of the model is that swings in strike incidence should be related to shifts in the composition of disputes. The benchmark model yields high elasticities for the impact of the model's parameters on dispute composition. In particular, the model implies that the composition should shift 
toward strikes the lower the real wage growth under the prior contract and the tighter the labor market conditions. To test this we estimate a logit model of the probability of a strike conditional on a labor dispute.

Table 7 gives the logistic marginal effects for the probability of a strike given a dispute. We find that real wage growth is consistently associated with a shift away from strikes. For the full sample, this effect is precisely measured when we include industry effects. A one standard deviation increase in the real wage measure is associated with nearly a three percentage point shift in the composition of disputes away from strikes. Similar to our earlier finding on uncertainty and dispute incidence, we find that the prior real wage effect is pronounced in negotiations before 1982 and switches signs in the post 1981 period.

The data also provide some weak support for the prediction that tight aggregate and industry labor market conditions shift the composition of disputes toward strikes. The magnitude and precision of the employment effects are much lower in the overall sample than in the pre 1981 sample. There is no evidence that deviations in state employment around trend have any impact on the composition of disputes. However, unions negotiating contracts in states with higher employment growth rates are less likely to select the strike threat.

The structure of union organization is also an important determinant of the composition of disputes. Holding constant the extent of union organization in the industry, increasing the concentration of the organization across different unions is associated with a shift away from strikes. The magnitude of this effect is quite large. A one standard deviation change in the Herfindhal index is associated with a five percentage point change in the dispute composition.

\section{Evidence of a Structural Change in Bargaining}

We see from the previous section that the relationship between stock price uncertainty and dispute incidence and between real wage changes and dispute composition are strong in the 1970s, and then disappear in the 1980s. This raises the general question of the stability over time of the empirical specification. The 1980s was a difficult decade for private sector unions in the United States. Proponents of amendments to the labor law that would prohibit firms from using replacement workers argue that there has been a fundamental change in bargaining practices following the demise of the air-traffic controllers' union PATCO in 1981. The Industrial Union Department of the AFL-CIO in a 1986 manual for union leaders titled The Inside Game: Winning With Workplace Strategies argue that the threat of permanent replacement has significantly diminished the attractiveness of the strike threat relative to the holdout threat: "To be sure, the strike in many cases is still a powerful and effective weapon. But when an employer begins trying to play by the 'new rules' and actually forces a strike, staying on the job and working from the inside may be more appropriate and effective" (p. 5, emphasis in original). In this section, we present a variety of tests of the null hypothesis that the structure of bargaining as reflected in our empirical model has been stable in the pre- and post- 1981 period.

Figure 4 shows the actual annual dispute incidence and the predicted annual dispute incidence based on the logit results in specification (1) of Table 6. The empirical model does a reasonable job of tracking the decline in dispute activity in the early 1980s. However, the model significantly under predicts the dispute incidence between 1985 and 1988. Overall, though, the model does capture the basic time series behavior in disputes. 


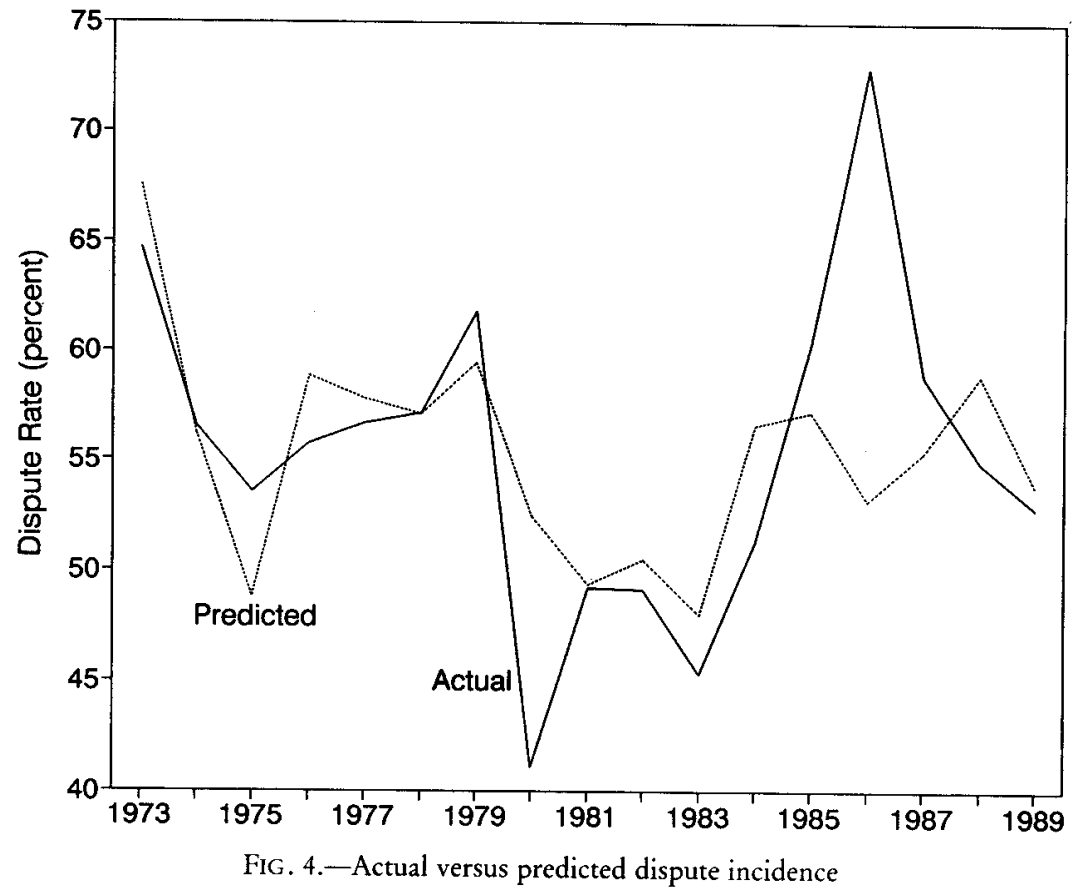

Without controlling for any covariates, dispute incidence in the post 1981 period is only 2.3 percentage points higher than in the earlier period, an insignificant difference. Once we control for changes in the underlying covariates, the difference increases to 7.5 percentage points and is significant. If we replace the post 1981 indicator with separate year effects for 1982 to 1989, we find the year effects are jointly significant although only 1986 is individually significant. The point estimate indicates that the actual dispute rate was 27 percentage points higher than predicted in 1986 . The $\chi^{2}$ statistic for the joint significance of the year effects is 21.9 with a probability value of 0.005 .

Turning to the composition of disputes, Figure 5 shows the actual annual fraction of disputes involving a strike and the predicted annual rates based on the logit results in specification (1) of Table 7. The empirical model tracks the shift in composition away from strikes in the late 1970s and early 1980s. However, the model predicts a trend upward in the use of the strike threat beginning in 1986 when the actual upswing did not occur until 1988.

Without controlling for any covariates, the fraction of disputes involving a strike is 13 percentage points lower in the post 1981 period, a significant difference. When we control for the covariates, the difference falls to 7.5 percentage points and is only marginally significant. Replacing the post 1981 indicator with year effects, we find that the year effects are jointly insignificant and that 1989 is the only year that is individually significant. The point estimate indicates that the actual fraction of disputes involving a strike was 18 percentage points lower than predicted in 1989. 


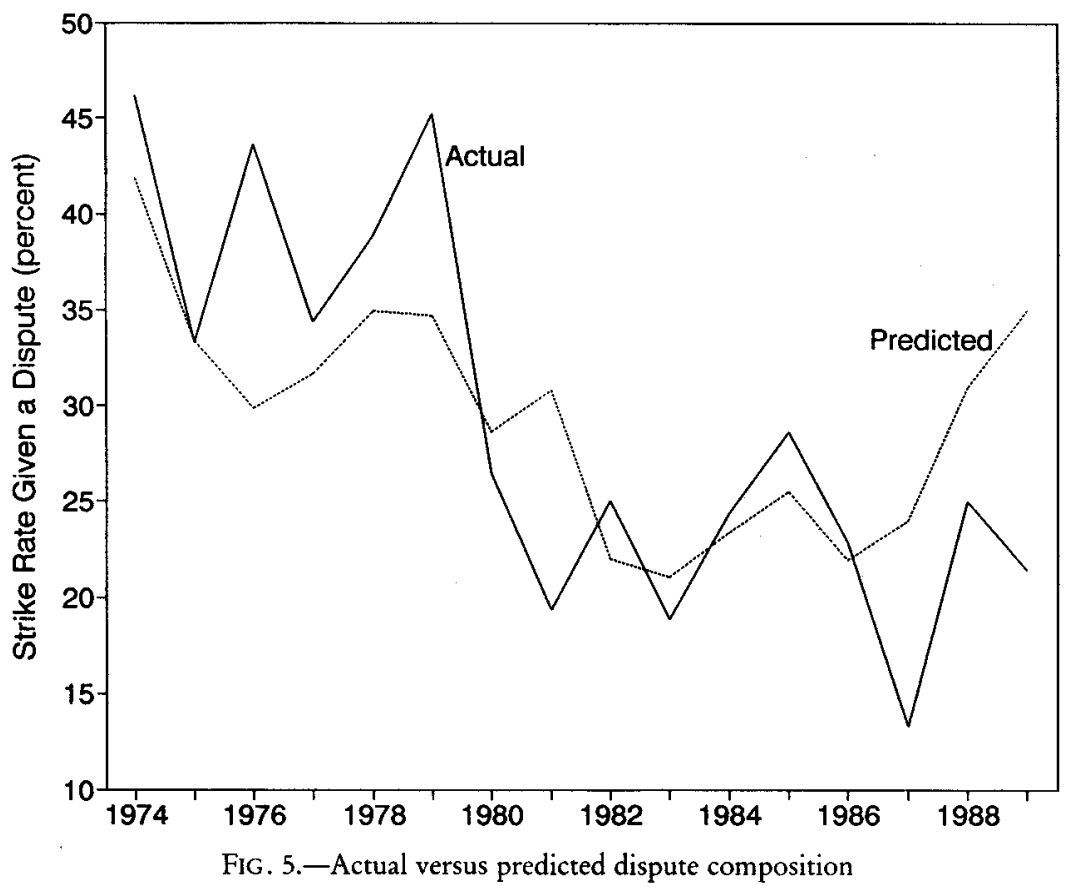

The data provide more evidence of a shift in the level of dispute activity than a shift in the composition of dispute activity in the 1980s. Comparing specifications (3) and (4) of Tables 6 and 7 also suggest that changes have occurred in the responsiveness of disputes to the underlying economic environment. To test this, we interacted each variable with a post 1981 indicator. The $\chi^{2}$ statistic (probability value) for the joint significance of the intercept and slope interactions in the dispute incidence specification is $19.7(0.10)$, and for the slope interactions alone is $16.0(0.25)$. While the interactions are jointly insignificant, the stock price uncertainty measure is individually significant. This is the key interaction from the viewpoint of the theory. The data indicate a reduction in the marginal effect associated with our uncertainty measure of 7 percentage points between the pre and post 1981 period, with a $t$-statistic of around 2.3.

Although the data do not indicate any significant overall reduction in the fraction of disputes involving a strike in the post 1981 period, there is more evidence of changes in the responsiveness of the threat choice to the economic environment. The $\chi^{2}$ statistic (probability value) for the joint significance of the intercept and slope interactions in the dispute composition specification is 26.1 (0.02), and for the slope interactions alone is 23.4 (0.02). The interactions on the industry employment residual and real wage change are both individually significant. The key interaction from the viewpoint of the theory is with the real wage effect. The data indicate an increase in the marginal effect of 13 percentage points between the pre and post 1981 period, with a $t$-statistic of 2.9 .

The threat of replacement workers reduces the relative attractiveness of the strike threat. If this threat was more pronounced in the post 1981 period, it would manifest itself in the dispute composition specification. ${ }^{18}$ Our data provide mixed evidence on the potential importance of replacements. On the one hand, there is little systematic evidence that the overall composition of disputes in the post 1981 period shifted away from strikes. However, there is strong evidence that the responsiveness of the threat choice to the underlying economic environment changed after 1981, perhaps because of a shift in the employer's bargaining tactics. If the use of permanent replacements is highest among firms negotiating wage concessions in the 1980s, and if some of these concessions (at least in real terms) occur during the prior contract, then we would expect fewer strikes in response to a real wage drop in the post 1981 period.

\footnotetext{
${ }^{18}$ One explanation for a greater use of permanent replacements in the 1980s is the large increase in union wage premiums. Wachter and Carter (1989) estimate that the union wage premium roughly doubled from the 1970s to the 1980s.
} 
Erosion of the real wage becomes a signal of concessionary bargaining and a heightened risk of replacement that significantly reduces the attractiveness of the strike threat. Further progress on this issue requires data on the threatened and actual use of replacement workers, which as yet is unavailable.

\section{Conclusion}

An important feature of U.S. labor contract negotiations is that most labor disputes do not involve a strike. If the contract expiration date is reached without a settlement, most bargaining units continue to negotiate under the terms of the expired contract, which we call holdout. We present a strategic bargaining model of labor contract negotiations that incorporates the union's threat choice-strike or holdout. The model makes predictions about the overall level of dispute activity and the form that disputes will take. The model predicts that the level of dispute activity is driven by the level of uncertainty over the value added by the union labor under a new contract. In addition, the model predicts that the composition of disputes will shift toward strikes when the real wage falls during the prior contract and when labor market conditions are tight.

We test these predictions by estimating logit models of the incidence and composition of labor disputes using U.S. data from 1970 to 1989 . We find empirical support for the model's key predictions, but that these associations are much weaker in the post 1981 period. An interpretation of these findings is that the threat of permanent replacements in the post 1981 period may have diminished the relative attractiveness of the strike threat.

\section{References}

Abowd, John M. "The Effects of International Competition on Collective Bargaining Settlements in the United States." In Immigration, Trade, and the Labor Market, edited by John M. Abowd and Richard B. Freeman. Chicago: University of Chicago Press, 1991.

Abowd, John M., and Freeman, Richard B. "The Internationalization of the U.S. Labor Market." In Immigration, Trade, and the Labor Market, edited by John M. Abowd and Richard B. Freeman. Chicago: University of Chicago Press, 1991.

Abowd, John M., and Tracy, Joseph S. "Market Structure, Strike Activity, and Union Wage Settlements." Industrial Relations 28 (Spring 1989): 227-250.

Admati, Anat R., and Perry, Motty. "Strategic Delay in Bargaining." Review of Economic Studies 54 (July 1987): 345-364.

Ausubel, Lawrence M., and Deneckere, Raymond J. "Separation and Delay in Bargaining." Working Paper, Northwestern University. 1991.

Bronars, Stephen; Deere, Donald; and Tracy, Joseph. "The Effect of Unions on Firm Behavior: An Empirical Analysis Using Firm-Level Data." Industrial Relations (1993): forthcoming.

Card, David. "Strikes and Bargaining: A Survey of Recent Empirical Literature." American Economic Review 80 (May 1990a): 410-415.

—. "Strikes and Wages: A Test of a Signalling Model." Quarterly Journal of Economics 105 (August 1990b): 625-659.

Cramton, Peter C., and Tracy, Joseph S. "Strikes and Holdouts in Wage Bargaining: Theory and Data." American Economic Review 82 (March 1992): 100-121.

_. "Wage Bargaining with Time-Varying Threats." Working Paper, Stanford University. 1993.

Gramm, Cynthia L.; Hendricks, Wallace E.; and Kahn, Lawrence M. "Inflation Uncertainty and Strike Activity." Industrial Relations 27 (Winter 1988): 114-129.

Industrial Union Department. The Inside Game: Winning with Workplace Strategies, Washington, DC: AFL-CIO, 1986.

Kennan, John. "Pareto Optimality and the Economics of Strike Duration." Journal of Labor Research 1 (Spring 1980): 77-94.

—. "The Economics of Strikes." In Handbook of Labor Economics. Volume II, edited by Orley 
Ashenfelter and Richard Layard. Amsterdam: Elsevier Science Publishers, 1986.

Kennan, John, and Wilson, Robert. "Strategic Bargaining Models and Interpretation of Strike Data." Journal of Applied Econometrics 4 (December 1989): S87-S130.

_- . "Can Strategic Bargaining Models Explain Collective Bargaining Data?" American Economic Review Papers and Proceedings 80 (May 1990): 405-409.

__ . "Bargaining with Private Information." Journal of Economic Literature 31 (March 1993):45104.

Lacroix, Robert. "A Microeconomic Analysis of the Effects of Strikes on Wages." Relations Industrielles 41 (1986): 111-126.

Lewis, H. Gregory. Union Relative Wage Effects: A Survey. Chicago: University of Chicago Press, 1986.

McConnell, Sheena. "Strikes, Wages, and Private Information." American Economic Review 79 (September 1989): 810-815.

Reder, Melvin, and Neumann, George. "Conflict and Contract: The Case of Strikes." Journal of Political Economy 88 (October 1980): 867-886.

Riddell, W. Craig. "The Effects of Strikes and Strike Length on Negotiated Wage Settlements." Working Paper, University of British Columbia. 1980.

Rubinstein, Ariel. "Perfect Equilibrium in a Bargaining Model." Econometrica 50 (January 1982): 97109.

Tracy, Joseph S. "An Empirical Test of an Asymmetric Information Model of Strikes." Journal of Labor Economics 5 (April 1987): 149-173.

Wachter, Michael L., and Carter, William H. "Norm Shifts in Union Wages: Will 1989 be a Replay of 1969?" Brookings Papers on Economic Activity, (1989): 233-264. 